\title{
Iron oxide colouring of highly-translucent 3Y-TZP ceramics for dental restorations
}

\author{
E. Willems ${ }^{a, b,{ }^{*},}$ F. Zhanga,b, B. Van Meerbeek ${ }^{b}$, J. Vleugels ${ }^{a}$ \\ ${ }^{a} K U$ Leuven (University of Leuven), Department of Materials Engineering, \\ Kasteelpark Arenberg 44, B-3001 Leuven, Belgium
}

${ }^{\mathrm{b}} K U$ Leuven (University of Leuven), Department of Oral Health Sciences, BIOMATBiomaterials Research Group \& UZ Leuven (University Hospitals Leuven), Dentistry, Kapucijnenvoer 7 blok a, B-3000 Leuven, Belgium

*Corresponding author: evita.willems@kuleuven.be

\begin{abstract}
The influence of $0.01-2$ mol\% $\mathrm{Fe}_{2} \mathrm{O}_{3}$ powder addition on the microstructure, mechanical and optical properties, and hydrothermal stability of highly-translucent 3YTZP ceramics is assessed and compared with commercially available co-precipitated $0.18 \mathrm{~mol} \% \mathrm{Fe}_{2} \mathrm{O}_{3}$ doped $\mathrm{ZrO}_{2}$ powder-based ceramics. Only those ceramics with up to $0.1 \mathrm{~mol} \% \mathrm{Fe}_{2} \mathrm{O}_{3}$ resulted in a proper shade for dental zirconia ceramics, with a typical composition of $87 \mathrm{vol} \% \mathrm{t}-\mathrm{ZrO}_{2}$ and $13 \mathrm{vol} \% \mathrm{c}-\mathrm{ZrO}_{2}$. The amount of cubic phase increased at higher $\mathrm{Fe}_{2} \mathrm{O}_{3}$ content. The hardness $(\sim 13 \mathrm{GPa})$ and fracture toughness $\left(\sim 3.6 \mathrm{MPa} \mathrm{m}{ }^{1 / 2}\right)$ of the $0.01 \mathrm{~mol} \%-0.1 \mathrm{~mol} \% \mathrm{Fe}_{2} \mathrm{O}_{3}$ doped $3 \mathrm{Y}$-TZP was comparable, whereas the hardness decreased above $0.5 \mathrm{~mol}_{2} \mathrm{Fe}_{2} \mathrm{O}_{3}$ and the fracture toughness decreased above $2 \mathrm{~mol} \% \mathrm{Fe}_{2} \mathrm{O}_{3}$. The hydrothermal ageing resistance slightly increased for $\mathrm{Fe}_{2} \mathrm{O}_{3}$ concentrations up to $1 \mathrm{~mol} \%$, whereas the translucency slightly decreased with increasing $\mathrm{Fe}_{2} \mathrm{O}_{3}$ content.
\end{abstract}

\section{Keywords}

zirconia, iron oxide, dental, restorative material, colouring

\section{Introduction}

Dental ceramics enable dentists to restore/replace teeth highly aesthetically [1]. Conventional porcelain-fused-to-metal (PFM) fixed dental prostheses (FDPs) do not provide a truly natural look, which requires metal-free full-ceramic FDPs [2]. Alternative conventional bi-layered zirconia crowns and bridges, consisting of a mechanically strong substructure veneered with aesthetic feldspatic porcelain however clinically often suffer from chipping defects of the veneering porcelain [2-4]. Therefore, highly translucent and colour-graded full-contour zirconia ceramics have been developed, but require further improvement of their mechanical properties and ageing resistance to fully replace PFM restorations [3].

3 mol\% yttria stabilized zirconia (3Y-TZP) is highly favoured for dental restorations because of its good strength and fracture toughness [5]. The high fracture toughness is provided by the inherent stress-induced tetragonal-to-monoclinic $(t \rightarrow m)$ phase transformation characteristic for zirconia ceramics $[6,7]$. The translucency of 3Y-TZP 
is on the other hand insufficient to match the translucency of natural teeth [8]. This is caused by porosities, birefringence and presence of scattering secondary phases [9]. Nowadays, the translucency of zirconia ceramics has been improved $[9,10]$ and starting powders for highly translucent zirconia are commercially available. The Zpex zirconia powder grade (Tosoh, Tokyo, Japan) is a nanosized co-precipitated 3Y-TZP powder with $0.05 \mathrm{wt} \%$ alumina dopant, instead of the more common $0.25 \mathrm{wt} \%$ alumina [11]. The reduced $\mathrm{Al}_{2} \mathrm{O}_{3}$ content increases the translucency of the sintered 3Y-TZP [9].

Natural teeth are however not as white as pure 3Y-TZP ceramics, requiring dental zirconia ceramics to be slightly coloured. One option to obtain tooth-coloured zirconia ceramics is to simply apply a coloured veneering layer $[5,12]$. Veneering layers on ceramic crowns however often chip and are not reliable enough for dental restorations [5]. Colouring zirconia can be done by staining with a colouring liquid or by adding a colorant additive or dopant to the powder mixture [13]. Staining can be done by immersion of the zirconia green body or pre-sintered body into a colouring liquid for a given time or by painting with a brush prior to sintering [14]. Several brands of staining solutions exist, each with their own pigment choices and composition. The surface colour will however fade over time and might be inhomogeneous [15]. On top of that, although debated, it has been reported that staining can decrease the mechanical properties of $\mathrm{ZrO}_{2}$ ceramics [16,17]. Hence, another option is to add dopants like iron and rare earth cations to colour the bulk ceramic [18]. Iron oxide doped 3Y-TZP starting powder is commercially available by from Tosoh (Grade Zpex Yellow) [11]. Coloured dental zirconia ceramics are also available on the market, such as Lava Esthetic (3M Oral Care, Seefeld, Germany), Vita YZ HtColor (Vita, Bad Säckingen, Switzerland) and Katana Zirconia (Kuraray Noritake, Tokyo, Japan).

This paper investigates the influence of iron oxide $\left(\mathrm{Fe}_{2} \mathrm{O}_{3}\right)$ doping on the microstructural, mechanical and optical properties, as well as the ageing kinetics of sintered Zpex (Tosoh) powder-based zirconia ceramics. Iron oxide $\left(\mathrm{Fe}_{2} \mathrm{O}_{3}\right)$ powder was added to the Zpex powder in different concentrations to achieve tooth-coloured zirconia ceramics and the results were compared using the commercially available coprecipitated $\mathrm{Fe}_{2} \mathrm{O}_{3}$-coloured Zpex Yellow (Tosoh) powder as reference.

\section{Experimental procedures}

\subsection{Materials preparation}

$\mathrm{ZrO}_{2}$ powder (Zpex, $40 \mathrm{~nm}$ particle size, Tosoh) was doped with $\mathrm{Fe}_{2} \mathrm{O}_{3}$ (98\% purity, 20-40 nm particle size, Alfa Aesar W, Ward Hill, MA, USA). Zpex powder is a commercially available co-precipitated $3 \mathrm{~mol} \%$ yttria stabilized (3Y-TZP) zirconia powder with 0.05 wt $\% \mathrm{Al}_{2} \mathrm{O}_{3}$ containing $3 \mathrm{wt} \%$ organic binder. Zpex Yellow powder (Tosoh) is a $3 \mathrm{wt} \%$ organic binder containing $3 \mathrm{Y}$-TZP powder that was co-precipitated with 0.15 wt $\%$ (0.18 mol\%) $\mathrm{Fe}_{2} \mathrm{O}_{3}$ and 0.05 wt $\% \mathrm{Al}_{2} \mathrm{O}_{3}$. 
Various amounts of iron oxide in the $0.01-2$ mol\% range were added to the Zpex powder and mixed on a multidirectional mixer (Turbula type T2C, Basel, Switzerland) for 24 hours in ethanol using 5-mm Y-TZP milling balls (grade TZ-3Y; Tosoh). The Zpex powder was debinded at $400^{\circ} \mathrm{C}$ for 1 hour prior to mixing with $\mathrm{Fe}_{2} \mathrm{O}_{3}$, dried and then sieve granulated $(315 \mu \mathrm{m})$. Green powder compacts (discs with a diameter of $\sim 20 \mathrm{~mm}$ and thickness of $\sim 4 \mathrm{~mm}$ ) were obtained by cold isostatically pressing (EPSI, Temse, Belgium) $\sim \mathrm{g}$ powder at $300 \mathrm{MPa}$ and pressureless sintered in air at $1450^{\circ} \mathrm{C}$ for $2 \mathrm{~h}$. The sintered zirconia ceramics are referred to as Zpex-xFe, with $\mathrm{x}$ indicating the mol\% of $\mathrm{Fe}_{2} \mathrm{O}_{3}$ dopant. Zpex and Zpex Yellow powder-based reference ceramics were pressed from as-received binder-containing powder and sintered under the same conditions. The density of all sintered, unpolished ceramics was measured in ethanol at the same moment using the Archimedes principle. The density of ethanol was determined before measurement. A theoretical density of $6.08 \mathrm{~g} / \mathrm{cm}^{3}$, the reported Tosoh value for Zpex, was used to calculate the residual porosity.

\subsection{Characterisation}

The fracture resistance $\left(\mathrm{K}_{\mathrm{I}}\right)$ and Vickers hardness $(\mathrm{Hv})$ of the sintered and polished materials were obtained from indentation measurements using a Vickers diamond indenter (Model FV700, Future Tech, Tokyo, Japan), applied with a load of $98 \mathrm{~N}$ for $15 \mathrm{~s}$. The Vickers indentation crack pattern was identified as a Palmqvist crack pattern, justifying the use of the formula of Niihara for the indentation fracture resistance measurement. The fracture resistance was also measured according to the formula of Anstis to allow a direct comparison with literature data. The reported values are the average and standard deviation of 10 indentations. The four-point bending strength of Zpex, Zpex-0.01Fe, Zpex-0.05Fe, Zpex-0.1Fe and Zpex Yellow ceramics was measured using ten bending bars of $45 \times 4 \times 3 \mathrm{~mm}^{3}$. These bars were prepared according to the ISO standards $[19,20]$. The strength was measured with an inner and outer span width of 20 and $40 \mathrm{~mm}$, respectively, and a crosshead speed of 0.5 $\mathrm{mm} / \mathrm{min}$.

X-Ray Diffraction (3003 T/T, Seifert, Ahrensburg, Germany) was used to determine the phase composition of all zirconia ceramics using $\mathrm{Cu}-\mathrm{K}_{\alpha}$ radiation at a voltage of 40 $\mathrm{kV}$ and a current of $40 \mathrm{~mA}$. Four discs of each composition were scanned over a range from $20^{\circ}$ to $90^{\circ} 2 \theta$ with a step width of $0.2^{\circ}$ and a scan speed of $2 \mathrm{~s} / \mathrm{step}$. The obtained XRD patterns were quantitatively analysed by Rietveld refinements using the Chebyshev II Polynomial Function in TOPAS-Academic software (Bruker AXS, Karlsruhe, Germany). Cubic, tetragonal and monoclinic zirconia phases were assumed to be present. The unit cell parameters of each phase were determined. All analysed scans had an R-value below $10 \%$ to assure the quality of the Rietveld refinement.

The microstructure, porosity and grain size of the sintered, thermally etched $\left(1250^{\circ} \mathrm{C}\right.$ for $25 \mathrm{~min}$ in air at a heating rate of $20^{\circ} \mathrm{C} / \mathrm{min}$ ) and platinum coated ceramics were analysed by scanning electron microscopy (SEM; XL30-FEG, FEI, Eindhoven, The 
Netherlands). The line intercept method was used to determine the grain size with the help of IMAGE-PRO software (Media Cybernetics, Rockville, MD USA). The average of at least 500 grains is reported with a correction factor of 1.56 [21].

The distribution of $\mathrm{Fe}^{3+}, \mathrm{Y}^{3+}, \mathrm{Al}^{3+}$ and $\mathrm{Zr}^{4+}$ cations at the grain boundaries of the $\mathrm{Zpex}-$ $0.1 \mathrm{Fe}$ ceramic was analysed using transmission electron microscopy (TEM; JEOL ARM 200F, Jeol, Tokyo Japan). Electron transparent samples were prepared by ionmilling with an lon Slicer (EM-09100IS, Jeol). TEM images were acquired by scanning transmission electron microscopy (STEM) operated at $200 \mathrm{kV}$. The distribution analysis of the cations was measured by energy dispersive spectroscopy (STEMEDS) using the Analysis Station software (Jeol). Elemental distribution maps around triple points were acquired and line analysis across the grain boundaries was performed. The atomic percentage of each element referring to the overall composition of the ceramic is given.

Three as-sintered discs of each zirconia composition were aged by in vitro accelerated hydrothermal testing. The zirconia discs were submerged in a stainless steel autoclave, partially filled with demineralized water. The autoclave was submerged in an oil bath at $134^{\circ} \mathrm{C}$. According to literature, " $1 \mathrm{~h}$ of autoclave treatment in steam at $134^{\circ} \mathrm{C}$ is theoretically the same as $3-4$ years in vivo at $37^{\circ} \mathrm{C}$ " [22]. The discs were removed from the autoclave at predefined times to measure the fraction of tetragonal phase that transformed to monoclinic phase using XRD (3003-TT, Seifert). Both sides of each disc were scanned so that a total of 6 surfaces of each composition were analysed. The volume fraction of formed monoclinic phase on the surface was calculated using the formula of Toraya et al. [23]. Before ageing, each side of the discs was scanned over the same range $\left(27.6^{\circ} \leq \theta \leq 31.7^{\circ}\right)$ to check whether any monoclinic phase was already present. The obtained degradation curves were fitted by the MehlAvrami-Johnson (MAJ) model [24] :

$$
\frac{\mathrm{V}_{\mathrm{m}}}{\mathrm{V}_{\mathrm{ms}}}=1-\exp \left(-(\mathrm{bt})^{\mathrm{n}}\right)
$$

with $\mathrm{V}_{\mathrm{ms}}$, the $m-\mathrm{ZrO}_{2}$ saturation level reached during hydrothermal ageing; $b$, the constant that describes the $t \rightarrow m$ transformation and $\mathrm{n}$, the constant that describes the mechanism of nucleation and growth of the monoclinic grains $[22,25]$.

The CIELAB coordinate for lightness $\left(\mathrm{L}^{*}\right)$ of the Zpex, Zpex Yellow, Zpex-0.01Fe, Zpex-0.05Fe and Zpex-0.1Fe ceramics was measured using a dental colorimeter (SpectroShade ${ }^{\mathrm{TM}}$ MICRO, MHT Optic Research, Niederhasli, Switzerland) with a calibration plate. Six discs of each composition were ground plan-parallel to a thickness of $0.5 \pm 0.05 \mathrm{~mm}$ and polished on both sides using colloidal silica (OPS, Struers, Maassluis, The Netherlands). The contrast ratio (CR) was determined using the ratio of illuminance of the material on a black $\left(Y_{b}\right)$ and white $\left(Y_{w}\right)$ background. The disc was adhered to the background with vaseline to improve the optical contact. The following equation was used: [26] 


$$
\mathrm{CR}=\frac{\mathrm{Y}_{\mathrm{b}}}{\mathrm{Y}_{\mathrm{w}}}
$$

The illuminance factor $(\mathrm{Y})$ for both is given by the following formula:

$$
\mathrm{Y}=\left(\frac{\mathrm{L}^{*}+16}{116}\right)^{3} \times \mathrm{Y}_{\mathrm{n}}
$$

in which $Y_{n}$ is assumed to be equal to 100, implying the white colour in simulated object colours is a perfect reflecting diffuser. Transparent materials have a CR value of 0.0 and 1.0 for completely opaque materials [27].

\section{Results and discussion}

The iron oxide doping resulted in a clear colouring of the zirconia ceramics, showing that simple admixing of $\mathrm{Fe}_{2} \mathrm{O}_{3}$ is a successful way of producing homogeneously coloured zirconia ceramics. Fig. 1 shows the six different experimental compositions that were prepared, as compared to the Zpex (Tosoh; non-coloured) and Zpex Yellow (Tosoh; 0.18 mol\% $\mathrm{Fe}_{2} \mathrm{O}_{3}$ ) reference formulations. The density is reported in Table 1. The $\mathrm{Fe}_{2} \mathrm{O}_{3}$-free zirconia (Zpex, Tosoh), the three lowest iron oxide-containing experimental zirconia formulations and the Zpex Yellow were nearly fully dense. At $\mathrm{Fe}_{2} \mathrm{O}_{3}$ contents $\geq 0.5 \mathrm{~mol} \%$, the residual porosity after $2 \mathrm{hrs}$ in air at $1450^{\circ} \mathrm{C}$ increases. Assuming a theoretical density of $6.08 \mathrm{~g} / \mathrm{cm}^{3}$ for Zpex, as stated by Tosoh, the porosity for pure Zpex is $0.12 \pm 0.05$ vol\%, 0.16 vol\%, 0.29 vol\% and 0.24 vol\% for $0.01,0.05$ and $0.1 \mathrm{Fe}$ respectively and $0.30 \pm 0.06$ vol\% for Zpex Yellow, whereas the ceramics with $\geq 0.5 \mathrm{~mol} \% \mathrm{Fe}_{2} \mathrm{O}_{3}$ contained some residual porosity (up to 1.73 vol \%).

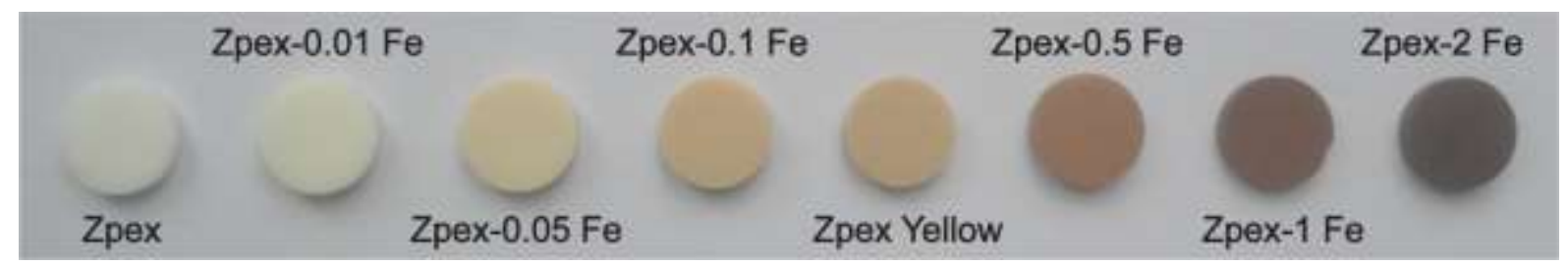

\begin{tabular}{|c|c|c|c|c|c|c|}
\hline Ceramic & $\begin{array}{l}\text { Theore } \\
\text { tical } \\
\text { density } \\
\left(\mathrm{g} / \mathrm{cm}^{3}\right)\end{array}$ & Density & $t-\mathrm{ZrO}_{2}$ & $c-\mathrm{ZrO}_{2}$ & $m-\mathrm{ZrO}_{2}$ & Porosity \\
\hline Zpex & 6.08 & $6.07 \pm 0.01$ & $86.9 \pm 0.5$ & $13.1 \pm 0.5$ & $0.0 \pm 0.0$ & $0.12 \pm 0.05$ \\
\hline Zpex-0.01Fe & 6.08 & $6.07 \pm 0.00$ & $87.3 \pm 0.4$ & $12.7 \pm 0.4$ & $0.0 \pm 0.0$ & $0.16 \pm 0.05$ \\
\hline Zpex-0.05Fe & 6.08 & $6.07 \pm 0.01$ & $87.0 \pm 0.5$ & $13.0 \pm 0.5$ & $0.0 \pm 0.0$ & $0.29 \pm 0.04$ \\
\hline Zpex-0.1Fe & 6.08 & $6.07 \pm 0.01$ & $86.0 \pm 0.6$ & $14.0 \pm 0.6$ & $0.0 \pm 0.0$ & $0.24 \pm 0.17$ \\
\hline Zpex Yellow & 6.08 & $6.06 \pm 0.01$ & $86.1 \pm 0.5$ & $13.9 \pm 0.5$ & $0.0 \pm 0.0$ & $0.30 \pm 0.06$ \\
\hline Zpex-0.5Fe & 6.08 & $6.04 \pm 0.02$ & $81.9 \pm 0.7$ & $18.1 \pm 0.7$ & $0.0 \pm 0.0$ & $0.63 \pm 0.09$ \\
\hline Zpex-1Fe & 6.08 & $6.04 \pm 0.01$ & $76.2 \pm 0.8$ & $23.8 \pm 0.8$ & $0.0 \pm 0.0$ & $0.62 \pm 0.13$ \\
\hline Zpex-2Fe & 6.08 & $5.99 \pm 0.01$ & $64.0 \pm 1.0$ & $33.1 \pm 2.3$ & $2.9 \pm 2.8$ & $1.73 \pm 0.42$ \\
\hline
\end{tabular}

Figure 1: $\mathrm{Fe}_{2} \mathrm{O}_{3}$-doped Zpex powder-based zirconia ceramics. 
Table 1: Density and phase composition, as obtained by XRD Rietveld analysis, of the zirconia ceramics as a function of the $\mathrm{Fe}_{2} \mathrm{O}_{3}$ concentration

\section{1 $\mathrm{Fe}_{2} \mathrm{O}_{3}$-doping promotes the formation of cubic $\mathrm{ZrO}_{2}$ phase}

The XRD patterns of the sintered zirconia ceramics are compared in Fig. 2, indicating similar patterns except for the 2 mol\% $\mathrm{Fe}_{2} \mathrm{O}_{3}$-doped ceramic that contains about 3 vol\% monoclinic $\mathrm{ZrO}_{2}$. A detailed analysis of the $72-76^{\circ} 2 \theta$ range, presented in Fig. 2, revealed that $\mathrm{Fe}_{2} \mathrm{O}_{3}$-doping favours the formation of the cubic $\mathrm{ZrO}_{2}$ phase which peaks can clearly be observed at around $74^{\circ} 2 \theta$. The quantitative results of the Rietveld analysis are presented in Table 1 . The up to $0.1 \mathrm{~mol} \% \mathrm{Fe}_{2} \mathrm{O}_{3}$-doped Zpex zirconia ceramics contain 13-14 vol\% cubic phase, which is comparable to the typical 15 vol\% cubic phase in $3 \mathrm{~mol} \%$ yttria stabilized zirconia (3Y-TZP) sintered at the same temperature $[28,29]$. With increasing $\mathrm{Fe}_{2} \mathrm{O}_{3}$ content, the amount of cubic phase content increased (Table 1). 0.5-2 mol\% $\mathrm{Fe}_{2} \mathrm{O}_{3}$ doping in 3Y-TZP was reported to induce cubic phase formation in Y-TZP next to the tetragonal phase [30]. $\mathrm{Fe}_{2} \mathrm{O}_{3}$ can hence be used as a sintering aid for cubic phase formation [31]. The lower density of the $0.5-2$ mol\% $\mathrm{Fe}_{2} \mathrm{O}_{3}$-doped zirconia ceramics is explained by the formation of cubic $\mathrm{ZrO}_{2}$ phase, which has a lower theoretical density $\left(5.99 \mathrm{~g} / \mathrm{cm}^{3}\right)$ [32], and by the presence of residual porosity (Table 1). 2 mol\% $\mathrm{Fe}_{2} \mathrm{O}_{3}$ addition resulted in $m-\mathrm{ZrO}_{2}$ phase formation, which may cause micro-cracks that lower the density even more. The high amount of cubic phase in the 2 mol\% $\mathrm{Fe}_{2} \mathrm{O}_{3}$-doped Zpex zirconia ceramics can cause a depletion of $\mathrm{Y}_{2} \mathrm{O}_{3}$ in the tetragonal phase [33]. When a fraction of the tetragonal phase around the cubic grains does not contain enough stabilizer, it will spontaneously transform during cooling from the sintering temperature, leading to the formation of $m-\mathrm{ZrO}_{2}$ phase and possible concomitant micro-cracks [34]. The tetragonality (c/a) of the $t-\mathrm{ZrO}_{2}$ phase increased with increasing $\mathrm{Fe}_{2} \mathrm{O}_{3}$ presence as well (Fig. 3d), which implies a higher phase transformability of the $t-\mathrm{ZrO}_{2}$ phase present [35]. This could as well explain the $m-\mathrm{ZrO}_{2}$ present in Zpex-2Fe. The commercial coprecipitated 0.18 mol\% $\mathrm{Fe}_{2} \mathrm{O}_{3}$ Zpex Yellow powder-based ceramic was fully dense and had the same amount of $t-\mathrm{ZrO}_{2}$ and $c-\mathrm{ZrO}_{2}$ phase as the pure $\mathrm{Fe}_{2} \mathrm{O}_{3}-$ free Zpex powder-based ceramic. There is no difference in the phase composition of the sintered $\mathrm{ZrO}_{2}$ ceramics when doping with low amounts of $\mathrm{Fe}_{2} \mathrm{O}_{3}(\leq 0.18 \mathrm{~mol} \%)$ by admixing or coprecipitation. The obtained density values allow to conclude that sintered pure $\mathrm{Fe}_{2} \mathrm{O}_{3}$-free $\mathrm{Zpex}$ (Tosoh), the 0.01-0.1 mol\% $\mathrm{Fe}_{2} \mathrm{O}_{3}$-doped zirconia ceramics and Zpex Yellow (Tosoh) can clinically be used for load bearing dental applications, since their density is over $6.00 \mathrm{~g} / \mathrm{cm}^{3}$ [19]. These ceramics also have less than 1 vol\% calculated porosity (Table 1 ) and can be considered fully dense. These zirconia ceramics have the right colour for dental applications, as shown in Fig. 1, whereas $\mathrm{Fe}_{2} \mathrm{O}_{3}$ levels $\geq 0.5 \mathrm{~mol} \%$ are too dark. 


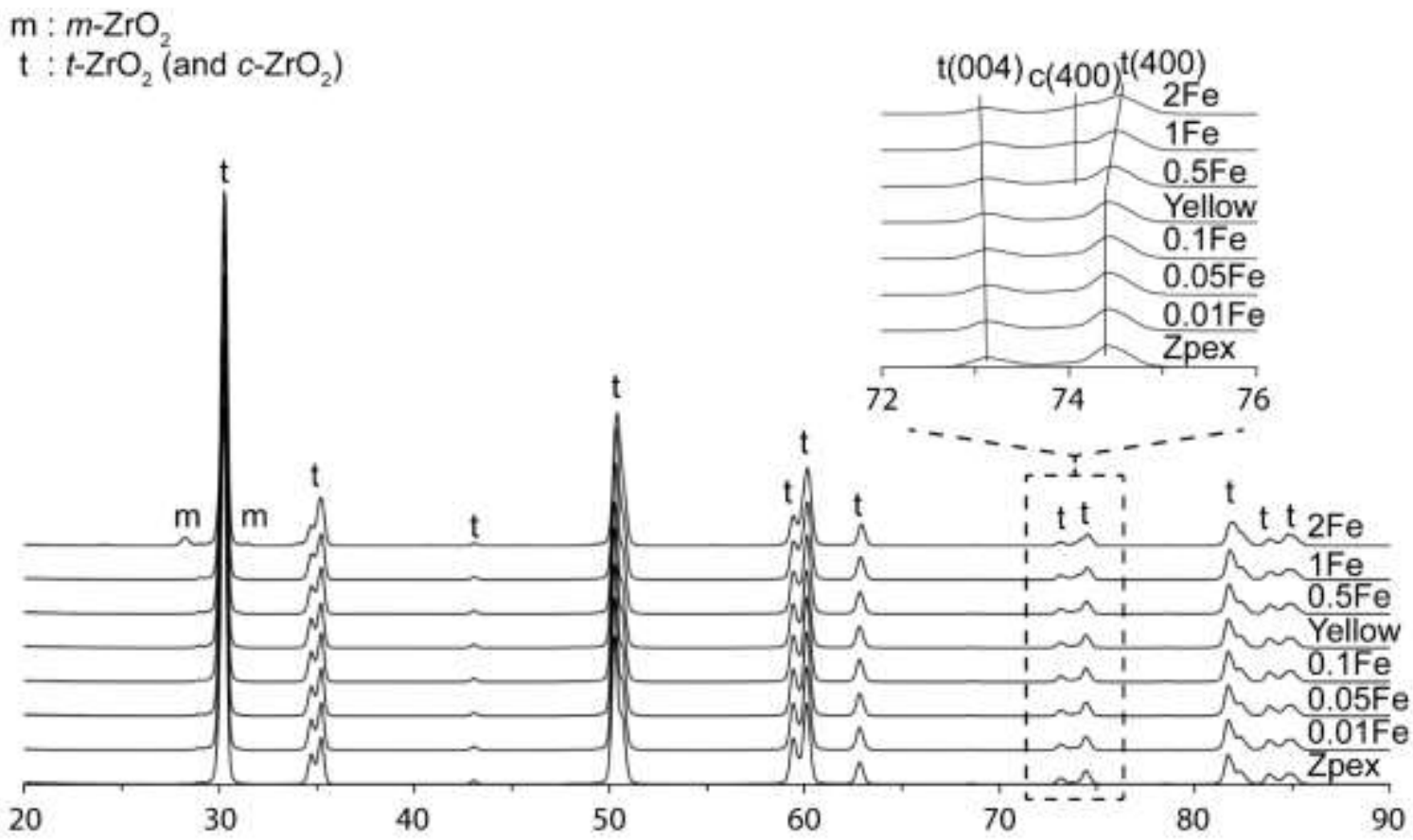

Figure 2: XRD patterns of the sintered zirconia ceramics as a function of the mol\% $\mathrm{Fe}_{2} \mathrm{O}_{3}$ dopant content.

Residual porosity and a decrease in density was observed at $\mathrm{Fe}_{2} \mathrm{O}_{3}$ contents above $0.5 \mathrm{~mol} \%$ (Table 1). A decrease of both tetragonal and cubic unit-cell parameters was measured as function of an increasing $\mathrm{Fe}_{2} \mathrm{O}_{3}$ content, as respectively shown in Fig. $3(a, b)$ and $(e)$. The decrease in cubic unit-cell parameter with increasing amount of $\mathrm{Fe}_{2} \mathrm{O}_{3}$ dopant was also reported in literature up to $0.5 \mathrm{~mol} \%$ [30]. $\mathrm{Fe}^{3+}$ cations substitute the larger $\mathrm{Zr}^{4+}$ cations, generating oxygen vacancies for charge neutralization, which reduces the dimensions of the cubic unit cell $[31,36]$. The decrease in cubic unit cell volume was more than 7 times larger than for the tetragonal phase, indicating that the $\mathrm{Fe}^{3+}$ cations mainly dissolved in the cubic phase. Despite the higher $\mathrm{Fe}_{2} \mathrm{O}_{3}$-doping of the cubic phase, it still has a lower density than the tetragonal phase, causing a decrease in the overall density with increasing amount of cubic phase present in the zirconia ceramic. Although enhanced densification with increasing $\mathrm{Fe}_{2} \mathrm{O}_{3}$ content was expected for admixed starting powders, as indicated in literature $[30,31,37]$.

No secondary phase particles were observed by XRD measurements (Fig. 2), Rietveld analysis (Table 1) or SEM (Fig. 4) in any of the ceramics, which means that the solubility limit of neither $\mathrm{Fe}_{2} \mathrm{O}_{3}$ nor $\mathrm{Al}_{2} \mathrm{O}_{3}$ was reached [30]. There is still a lot of uncertainty about the solubility limit of $\mathrm{Fe}_{2} \mathrm{O}_{3}$ in zirconia. In fact, a high range of solubility limits have been reported for $\mathrm{Fe}_{2} \mathrm{O}_{3}$ in zirconia $[31,38]$. The solubility limit of 2-3 mol\% $\mathrm{Fe}_{2} \mathrm{O}_{3}$ in $c-\mathrm{ZrO}_{2}$ was reported by Verkerk et al. [31]. Stefanic et al. reported a solubility limit of $2 \mathrm{~mol} \%$ in sintered $\mathrm{ZrO}_{2}$ and observed the formation of monoclinic phase when the solubility limit was exceeded [38]. The latter finding could be another explanation for the formation of $m-\mathrm{ZrO}_{2}$ phase in $2 \mathrm{~mol} \% \mathrm{Fe}_{2} \mathrm{O}_{3}$-doped $\mathrm{Zpex}$ zirconia 
ceramics. Our research shows that up to $2 \mathrm{~mol} \%$ of $\mathrm{Fe}_{2} \mathrm{O}_{3}$ can be dissolved in 3Y-TZP when sintering at $1450^{\circ} \mathrm{C}$ for 2 hours. The $\mathrm{Fe}^{3+}$ cations will diffuse easily into the lattice during sintering.

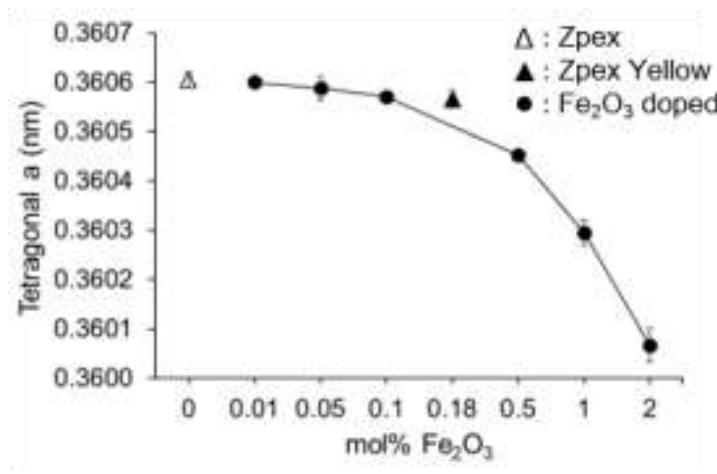

(a) a parameter $t-\mathrm{ZrO}_{2}(\mathrm{~nm})$

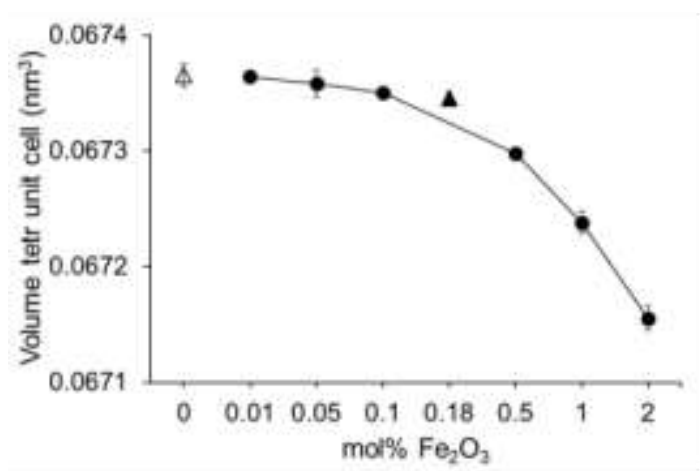

(c) Tetragonal unit cell volume $\left(\mathrm{nm}^{3}\right)$

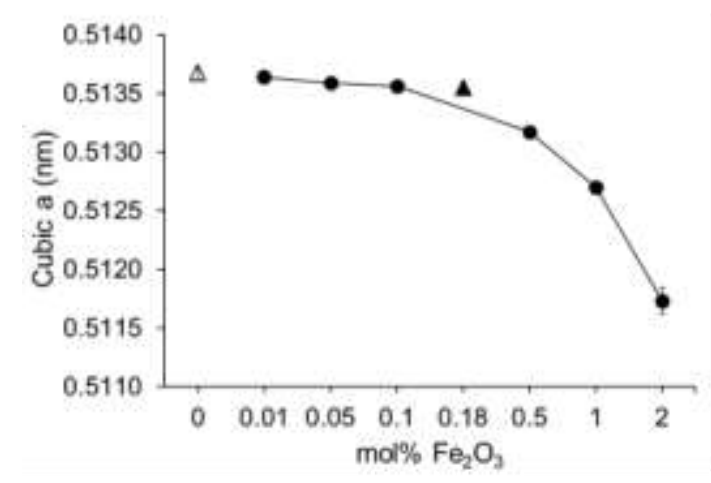

(e) a parameter $c-\mathrm{ZrO}_{2}(\mathrm{~nm})$

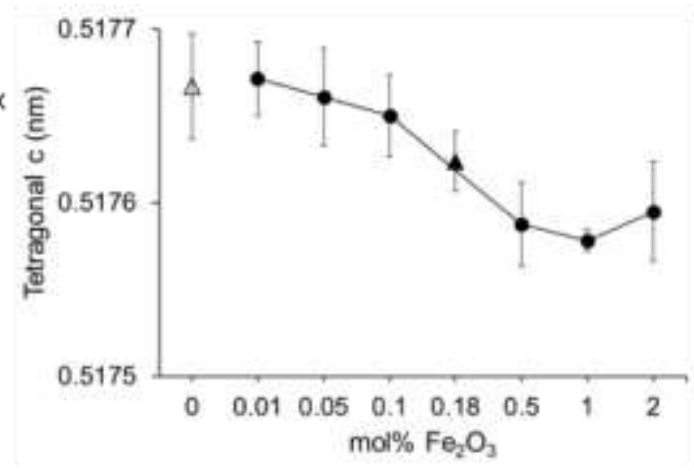

(b) c parameter $t-\mathrm{ZrO}_{2}(\mathrm{~nm})$

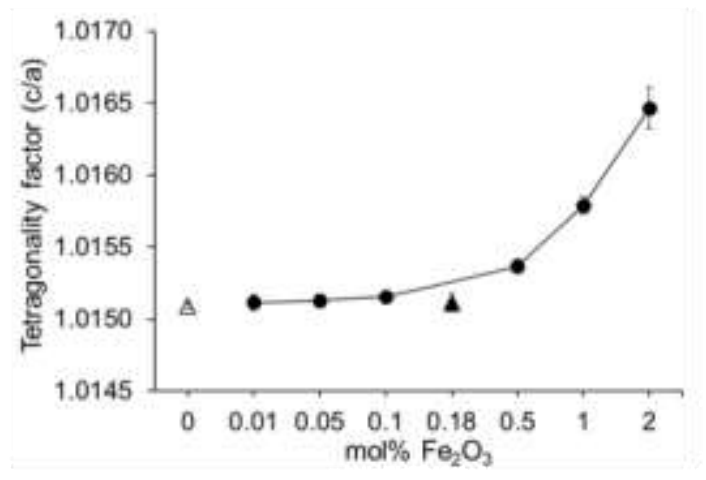

(d) Tetragonality of the $\mathrm{ZrO}_{2}$ phase

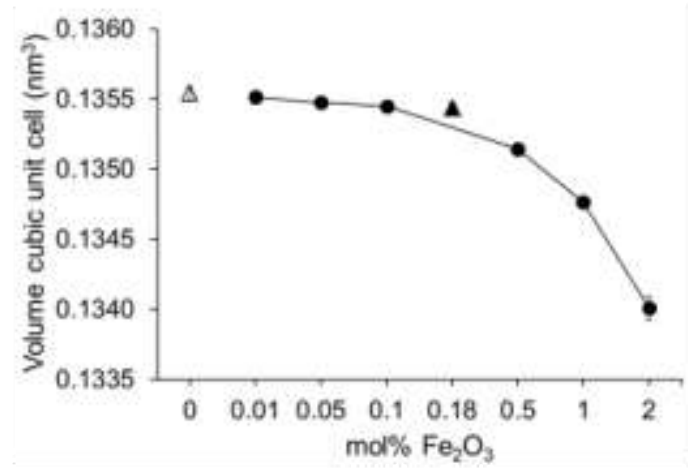

(f) Cubic unit cell volume $\left(\mathrm{nm}^{3}\right)$

Figure 3: Unit cell dimensions of the $t$ - and $c-\mathrm{ZrO}_{2}$ phases in Zpex, Zpex Yellow and $\mathrm{Fe}_{2} \mathrm{O}_{3}$ doped Zpex zirconia ceramics. 


\begin{tabular}{|c|c|c|c|c|c|c|}
\hline Ceramic & $\begin{array}{c}\text { Grain size } \\
(\mathrm{nm})\end{array}$ & $\begin{array}{c}\mathrm{H}_{\mathrm{V}} \\
(\mathrm{GPa})\end{array}$ & $\begin{array}{c}\mathrm{K}_{\mathrm{IC}} \\
\text { (Niihara) } \\
\left(\mathrm{MPa} \mathrm{m}^{1 / 2}\right)\end{array}$ & $\begin{array}{c}\mathrm{K}_{\mathrm{IC}} \\
\text { (Anstis) } \\
\left(\mathrm{MPa} \mathrm{m}^{1 / 2}\right)\end{array}$ & $\begin{array}{c}\sigma_{\mathrm{b}} \\
(\mathrm{MPa})\end{array}$ & CR \\
\hline Zpex & $437 \pm 174$ & $13.3 \pm 0.2$ & $4.9 \pm 0.1$ & $3.6 \pm 0.2$ & $883 \pm 102$ & $0.44 \pm 0.01$ \\
\hline Zpex-0.01Fe & $426 \pm 176$ & $13.2 \pm 0.1$ & $4.8 \pm 0.1$ & $3.6 \pm 0.1$ & $550 \pm 85$ & $0.45 \pm 0.02$ \\
\hline Zpex-0.05Fe & $440 \pm 185$ & $13.1 \pm 0.1$ & $4.8 \pm 0.1$ & $3.6 \pm 0.2$ & $516 \pm 46$ & $0.47 \pm 0.01$ \\
\hline Zpex-0.1Fe & $437 \pm 182$ & $13.1 \pm 0.1$ & $4.8 \pm 0.1$ & $3.7 \pm 0.1$ & $446 \pm 36$ & $0.52 \pm 0.01$ \\
\hline Zpex Yellow & $428 \pm 171$ & $13.1 \pm 0.3$ & $4.8 \pm 0.2$ & $3.6 \pm 0.3$ & $885 \pm 134$ & $0.65 \pm 0.07$ \\
\hline Zpex-0.5Fe & $488 \pm 206$ & $12.6 \pm 0.1$ & $4.7 \pm 0.2$ & $3.5 \pm 0.3$ & l & I \\
\hline Zpex-1Fe & $599 \pm 265$ & $12.2 \pm 0.1$ & $4.8 \pm 0.2$ & $3.6 \pm 0.3$ & I & I \\
\hline Zpex-2Fe & $641 \pm 395$ & $11.6 \pm 0.1$ & $4.5 \pm 0.1$ & $3.3 \pm 0.1$ & I & I \\
\hline
\end{tabular}

$H_{V}$ : Vickers hardness; KIC: Fracture toughness; $\sigma_{b}$ : Bending strength; CR: Contrast ratio

Table 2: Density, grain size and mechanical properties of the zirconia ceramics

\subsection{Influence $\mathrm{Fe}_{2} \mathrm{O}_{3}$-doping on the mechanical properties of $3 \mathrm{Y}$-TZP ceramics}

The highest $\mathrm{Fe}_{2} \mathrm{O}_{3}$ additions $\left(0.5-2\right.$ mol\% $\left.\mathrm{Fe}_{2} \mathrm{O}_{3}\right)$ resulted in a significantly larger average grain size and a bimodal grain size distribution was formed, as can be observed in the SEM pictures in Fig. 4 and as reported in Table 2. The large grains are most probably cubic grains [39]. All mechanical property data can be found in Table 2. The hardness decreased for samples with a $\mathrm{Fe}_{2} \mathrm{O}_{3}$ content above $0.5 \mathrm{~mol} \%$. The indentation fracture resistance data are within the 4.5-4.9 $\mathrm{MPa} \mathrm{m}{ }^{1 / 2}$ range, corresponding to what is reported in literature [40]. Only Zpex-2Fe shows a decrease in fracture toughness. The bending strength of Zpex and Zpex Yellow is similar and comparable to what can be found in literature [41]. A strong decrease in bending strength was observed for the $\mathrm{Fe}_{2} \mathrm{O}_{3}$-doped admixed ceramics.
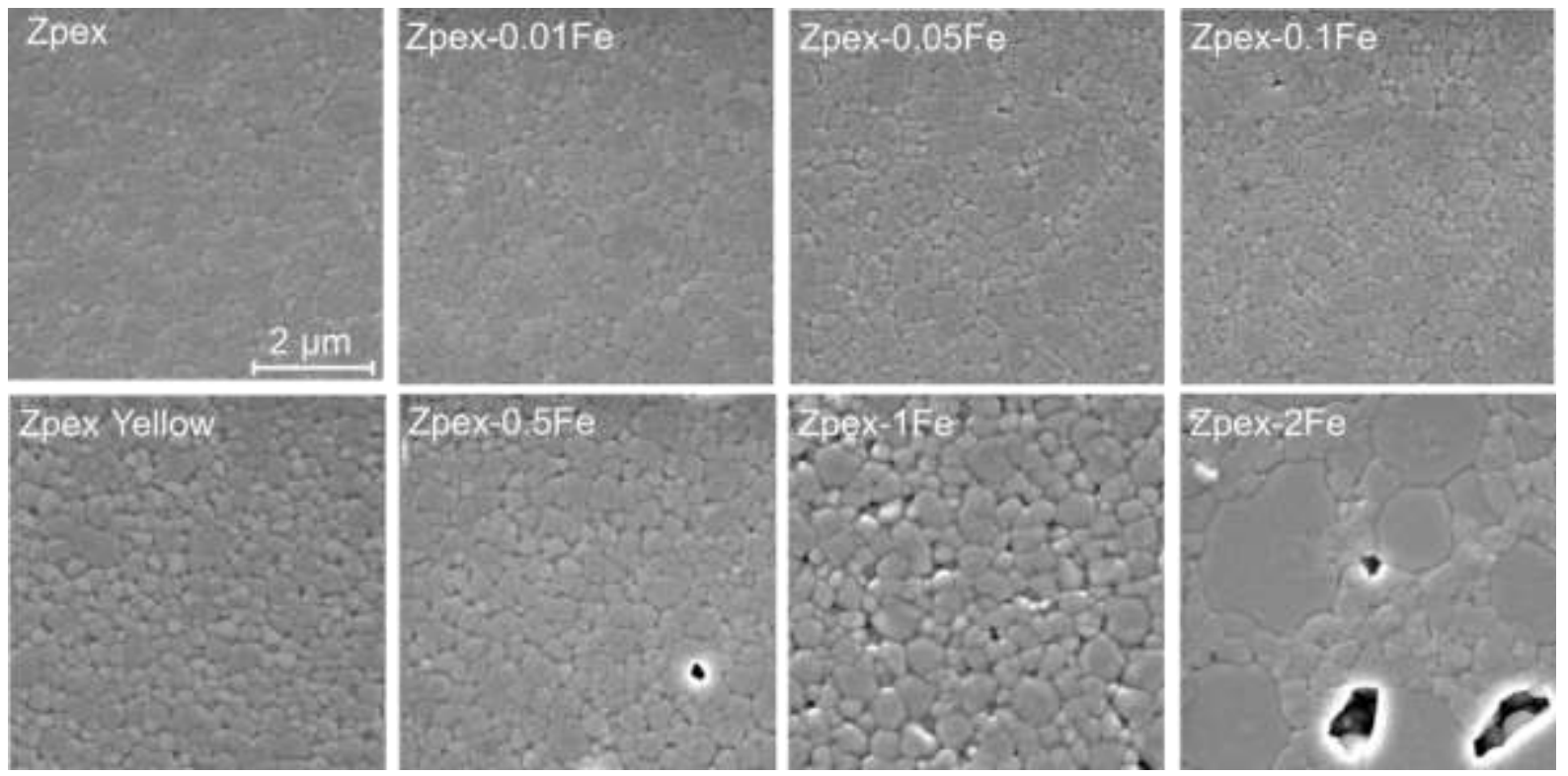

Figure 4: Scanning electron micrographs of iron oxide doped zirconia ceramics. 
The addition of $\mathrm{Fe}_{2} \mathrm{O}_{3}$ promotes grain growth, most explicitly for the cubic phase [30] and the cubic grains in a 3Y-TZP grow faster than the tetragonal grains [42], which explains the increase in average grain size. The increase in grain size combined with the increase in porosity for the three highest $\left(0.5-2\right.$ mol\%) $\mathrm{Fe}_{2} \mathrm{O}_{3}$-content ceramics explains the decrease in hardness of these zirconia ceramic formulations [43,44]. Pure $\mathrm{Fe}_{2} \mathrm{O}_{3}$-free $\mathrm{Zpex}, \mathrm{Fe}_{2} \mathrm{O}_{3}$ coloured Zpex Yellow and 0.01-0.1 mol\% $\mathrm{Fe}_{2} \mathrm{O}_{3}$-doped Zpex have a rather small grain size around $440 \mathrm{~nm}$. Zhang et al. reported a minimum Anstis fracture toughness of $\sim 3.8 \mathrm{MPa} \mathrm{m} \mathrm{m}^{1 / 2}$ for non-transformable $3 \mathrm{Y}$-TZP with an uncorrected grain size of 200-250 $\mathrm{nm}$ [45]. With increasing grain size, the fracture toughness slightly increased to $\sim 4.0 \mathrm{MPa} \mathrm{m} \mathrm{m}^{1 / 2}$ due to an increased phase transformability and concomitant transformation toughening contribution [45]. A smaller $t-\mathrm{ZrO}_{2}$ grain size lowers the transformation toughening mechanism $[46,47]$. The grain size could be increased by sintering the ceramics at higher temperature $[45,46,48]$. However, by increasing the transformability of zirconia ceramics, hydrothermal ageing will also become a bigger issue [49]. The higher amount of cubic phase explains the slightly lower fracture toughness of the $2 \mathrm{~mol} \% \mathrm{Fe}_{2} \mathrm{O}_{3}$-doped zirconia ceramic, since there is less tetragonal $\mathrm{ZrO}_{2}$ that can transformation toughen. The 0.5 and 1 mol\% $\mathrm{Fe}_{2} \mathrm{O}_{3}$-doped ceramics remarkably did not show a decrease in fracture toughness, whereas they contain a higher amount of non-transformable cubic phase. The (400) and (004) tetragonal peak shifts in Fig. 2 indicate that the separation between the tetragonal (400) and (004) peaks increased with increasing $\mathrm{Fe}_{2} \mathrm{O}_{3}$ content above $0.18 \mathrm{~mol} \%$. The tetragonality of the $t-\mathrm{ZrO}_{2}$ phase also increased with increasing $\mathrm{Fe}_{2} \mathrm{O}_{3}$ content, especially above $0.18 \mathrm{~mol} \%$. This tetragonality increase should be attributed to a lower amount of $\mathrm{Y}_{2} \mathrm{O}_{3}$ in the tetragonal grains, since more $\mathrm{Y}_{2} \mathrm{O}_{3}$ is consumed to stabilize the cubic phase. The higher tetragonality in these ceramics could also facilitate the $t \rightarrow m$ transformation toughening [35]. Despite the reduced $t$ $\mathrm{ZrO}_{2}$ content in the ceramics with an $\mathrm{Fe}_{2} \mathrm{O}_{3}$ content above $0.18 \mathrm{~mol} \%$, the fracture resistance was maintained due to an increased $t-\mathrm{ZrO}_{2}$ phase tetragonality and concomitant transformability.

The admixed ceramics have a sudden and strong decrease in the average bending strength. The fracture surfaces showed relatively large defects that were present in the mixed ceramics (Fig. 5). Using the formula of Griffith and the data reported in Table 2, the critical flaw size ranges from 14,15 to $22 \mu \mathrm{m}$ in $0.01,0.05$ and $0.1 \mathrm{~mol}_{\%} \mathrm{Fe}_{2} \mathrm{O}_{3}$ doped Zpex respectively. The larger defects in the admixed ceramics were probably introduced during processing due to the fact that the as-received Zpex starting powder was debinded prior to $\mathrm{Fe}_{2} \mathrm{O}_{3}$ admixing and compaction was done without binder addition, in contrast to the as-received binder containing Zpex and Zpex Yellow reference grades. Skipping the debinding prior to the compaction could have minimized the formation of microdefects and improve the bending strength of the ceramics. It would have caused an inhomogeneous distribution of the $\mathrm{Fe}_{2} \mathrm{O}_{3}$ powder on the other hand. 

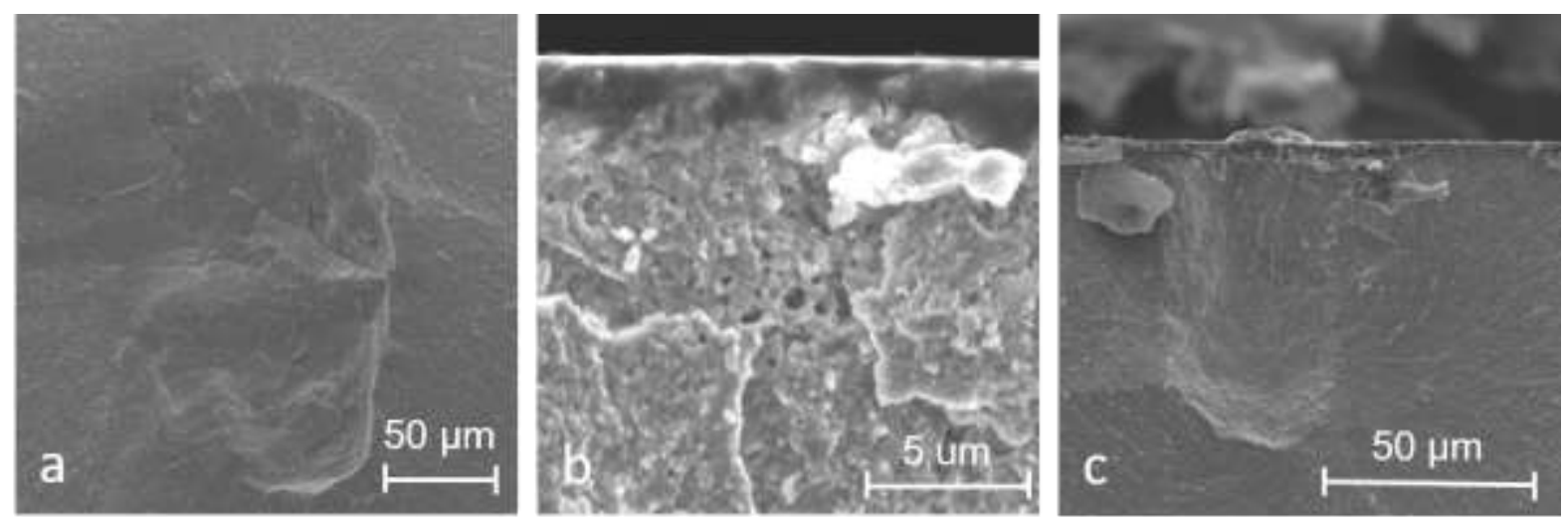

Figure 5: SEM images of defects and pores observed on fracture surfaces of Zpex0.1Fe 4-point bending bars: (a) defect inside the ceramic, (b) porosity and (c) surface defect with hackle lines.

The commercial $\mathrm{Fe}_{2} \mathrm{O}_{3}$-free $\mathrm{Zpex}$ and 0.18 mol\% $\mathrm{Fe}_{2} \mathrm{O}_{3}$ doped Zpex Yellow powderbased ceramics had a similar $t-\mathrm{ZrO}_{2}$ phase tetragonality, $c-\mathrm{ZrO}_{2}$ phase content, grain size, hardness, fracture toughness and bending strength. Interesting to note in Table 1 is that the Zpex Yellow grade has the highest amount of $\mathrm{Fe}_{2} \mathrm{O}_{3}$ that still corresponds to the $t+c$ content of the non-doped 3Y-TZP. Moreover, 0.18 mol\% $\mathrm{Fe}_{2} \mathrm{O}_{3}$ addition is also the highest investigated dopant content, above which the unit cell parameters of both $t+c-\mathrm{ZrO}_{2}$ and the $t-\mathrm{ZrO}_{2}$ phase tetragonality starts to change (see Fig. 3).

\subsection{Segregation of $\mathrm{Fe}^{3+}$ influences the low-temperature degradation}

The hydrothermal ageing curves (Fig. 6(a,b)) and kinetic parameter b (Table 3) show that the $\mathrm{Fe}_{2} \mathrm{O}_{3}$ doping had a positive effect on the hydrothermal stability of zirconia ceramics up to $1 \mathrm{~mol} \%$. Please note that although less monoclinic content was formed in the $0.5,1$ and 2 mol\% $\mathrm{Fe}_{2} \mathrm{O}_{3}$-doped zirconia, there was less tetragonal zirconia available and the saturation level was lower. Both undoped Zpex references (Zpex and Zpex Yellow) show a rather fast hydrothermal degradation compared to $0.25 \mathrm{wt} \%$ $\mathrm{Al}_{2} \mathrm{O}_{3}$ containing 3Y-TZP (grade TZ-3YE, Tosoh) (Fig. 6.a and Table 3) due to the low amount $(0.05 \mathrm{wt} \%)$ of alumina present in these zirconia ceramics [50]. $\mathrm{Fe}_{2} \mathrm{O}_{3}$ doping had a positive effect on hydrothermal stability, but is not as effective as $\mathrm{Al}_{2} \mathrm{O}_{3}$ doping of 3Y-TZP. 


\begin{tabular}{lclc}
\hline Ceramic & $\mathbf{V}_{\mathbf{m s}}(\mathbf{v o l} \%)$ & $\mathbf{b}\left(\mathbf{h}^{-1}\right)$ & $\mathbf{n}$ \\
\hline Zpex & 85.5 & 0.088 & 1.487 \\
Zpex-0.01Fe & 84.9 & 0.082 & 1.515 \\
Zpex-0.05Fe & 84.7 & 0.077 & 1.570 \\
Zpex-0.1Fe & 83.7 & 0.074 & 1.573 \\
Zpex Yellow & 83.1 & 0.084 & 1.599 \\
Zpex-0.5Fe & 77.0 & 0.048 & 1.176 \\
Zpex-1Fe & $57.1^{*}$ & $0.015^{*}$ & $0.570^{*}$ \\
Zpex-2Fe & 52.5 & 0.055 & 0.513 \\
TZ-3Y-E & 87.1 & 0.032 & 1.586
\end{tabular}

$\mathrm{V}_{\mathrm{ms}}: m-\mathrm{ZrO}_{2}$ saturation level; b: constant describing $t \rightarrow m$ transformation; $\mathrm{n}$ : constant describing mechanism of nucleation and growth monoclinic grains

*Saturation level not reached, values are only indicative.

Table 3: Ageing kinetics of the sintered zirconia ceramics

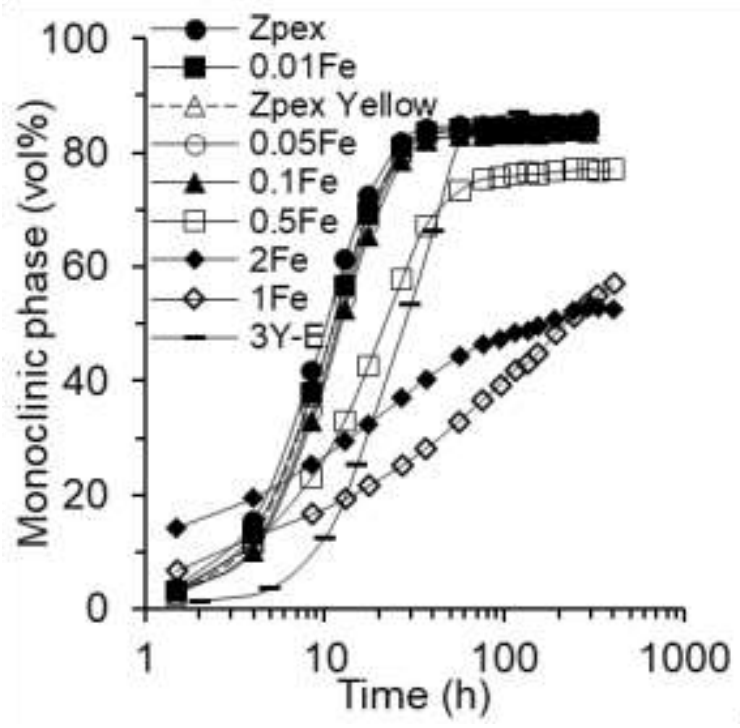

(a) Overview of ageing curves and comparison to TZ-3Y-E

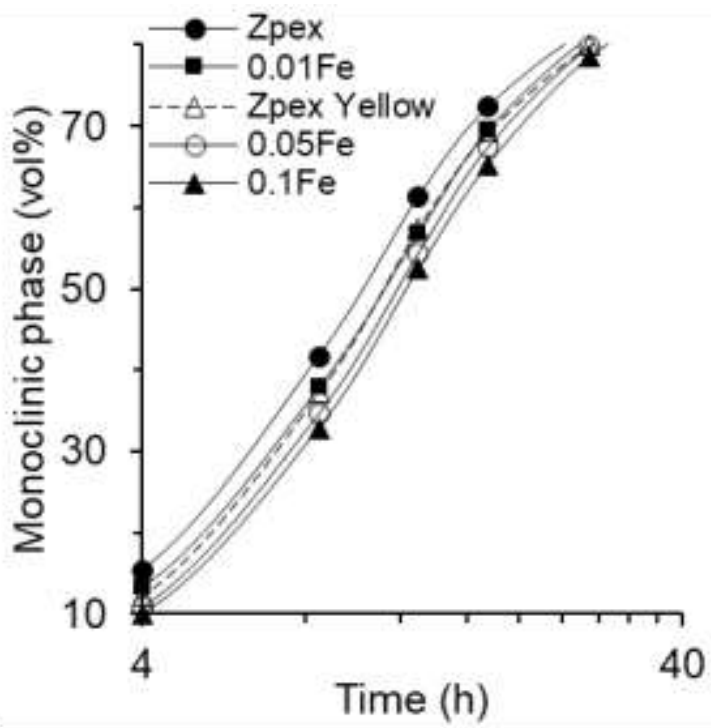

(b) Close up of Zpex, Zpex Yellow and $Z$ pex-0.01, 0.05 and $0.1 \mathrm{Fe}$

Figure 6: Ageing curves of white $\left(\mathrm{Fe}_{2} \mathrm{O}_{3}\right.$-free $)$, and coloured Zpex zirconia ceramics sintered for $2 \mathrm{~h}$ at $1450^{\circ} \mathrm{C}$

Almost all trivalent cationic dopants preferentially segregate at the grain boundaries of 3Y-TZP ceramics, hereby following the space-charge layer concept introduced by Hwang et al. [51]. In this specific case, the $\mathrm{Y}^{3+}, \mathrm{Al}^{3+}$ and $\mathrm{Fe}^{3+}$ dopants segregate to the space charge layer, as proven by the STEM photomicrograph and EDS element mapping of the Zpex-0.1Fe shown in Fig. 7. Although $\mathrm{Fe}^{3+}$ cations were observed throughout the bulk of the grains, $\mathrm{Fe}^{3+}$ clearly had a preference to segregate at the grain boundaries. The $\mathrm{Fe}^{3+}$ cation was dispersed over the entire lattice because of the rather small radius difference between $\mathrm{Fe}^{3+}(78 \mathrm{pm})$ and $\mathrm{Zr}^{4+}(84 \mathrm{pm})$ [36,52]. Despite the small size mismatch, there is an electrical driving force that drives the $\mathrm{Fe}^{3+}$ cations towards the grain boundary [53]. These cations will diffuse along the forming grain 
boundaries during sintering. Since $\mathrm{Fe}^{3+}$ cations $(78 \mathrm{pm})$ are smaller than the slow diffusing $\mathrm{Y}^{3+}$ cations (101.9 pm) and smaller than the $\mathrm{Zr}^{4+}$ cations $(84 \mathrm{pm}$ ), it is believed they will diffuse faster and dissolve easily into the lattice up to a few mol\% [42,54]. Next to the space charge layer concept, the $\mathrm{Al}^{3+}$ segregation at the grain boundary can also be explained by the low solubility of $\mathrm{Al}_{2} \mathrm{O}_{3}$ in zirconia at room temperature. There is only a very small amount of $\mathrm{Al}_{2} \mathrm{O}_{3}(0.05 \mathrm{wt} \%)$ present in the zirconia ceramic. The solubility of $\mathrm{Fe}^{3+}$ is much higher, which makes it easier for the $\mathrm{Fe}^{3+}$ cations to settle in the lattice [55]. The cation dopant size also has an influence on the lowtemperature degradation of zirconia. A higher radius mismatch, either larger or smaller, results in a more favourable hydrothermal ageing stability due to the stronger

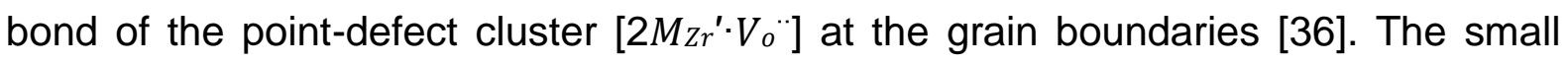
amount of $\mathrm{Fe}^{3+}$ dopant and the relatively small cation size mismatch between $\mathrm{Zr}^{4+}$ and $\mathrm{Fe}^{3+}$ could explain the small improvement in ageing resistance. The segregated $\mathrm{Fe}^{3+}$ cations at the grain boundary bind the oxygen vacancies $\left(0.9 \mathrm{eV}\left[2 \mathrm{Fezr}^{\prime} \cdot \mathrm{V}_{\circ}{ }^{\prime \prime}\right]\right.$ bonding energy), retarding the ageing kinetics [56]. This bonding energy is even slightly higher than for $\mathrm{Y}^{3+}$ cations $\left(0.65 \mathrm{eV}\left[2 \mathrm{YZr}^{\prime} \cdot \mathrm{V}_{o}{ }^{\prime \prime}\right]\right.$ bonding energy). [56] However, because there is only a small radius difference, the bond between the $\mathrm{Fe}^{3+}$ cations and the oxygen vacancies is not that strong [36,56]. This underlines the importance of alumina in zirconia ceramics. Doping zirconia with $\mathrm{Al}^{3+}$ can improve the ageing kinetics due to the stronger bonding with the oxygen vacancies (1.27 eV [2Alzr' $\left.{ }^{\prime} V_{o}{ }^{\prime \prime}\right]$ bonding energy) [56].

Interestingly, the Zpex Yellow did not show the positive retarding ageing effect as explicitly as the coated $\mathrm{Zpex}-\mathrm{Fe}_{2} \mathrm{O}_{3}$ mixtures. The co-precipated Zpex Yellow powder has less grain boundary segregation of the $\mathrm{Fe}^{3+}$ cations than the admixed powder mixes. We can state that admixing of the $\mathrm{Fe}_{2} \mathrm{O}_{3}$ colouring dopant has a slight advantage over co-precipitating in case of ageing kinetics. Grain boundary cation segregation can further be improved by using coated 3Y-TZP powder [45].

The degradation curves (Fig. 6) and kinetic parameter b (Table 3) indicate that the $\mathrm{Fe}_{2} \mathrm{O}_{3}$ doping had a positive influence on the hydrothermal stability of Zpex up to 1 mol\%. Please note that from 2 mol\% $\mathrm{Fe}_{2} \mathrm{O}_{3}$ the kinetic parameter $b$ increases again (Table 3), indicating a decrease in hydrothermal ageing resistance. The unstable, yttria-depleted tetragonal grains that surround the cubic grains, could cause this faster transformation rate because they are easier transformed into monoclinic phase $[34,57]$. The higher amount of non-transformable cubic phase in these ceramics can explain the decrease in the formation of $m-\mathrm{ZrO}_{2}$. The $1 \mathrm{~mol} \% \mathrm{Fe}_{2} \mathrm{O}_{3}$-doped $\mathrm{Zpex}$ zirconia ceramics did not reach the $m-\mathrm{ZrO}_{2}$ saturation level after $400 \mathrm{hrs}$ of testing, implying a substantial amount of maintained $t-\mathrm{ZrO}_{2}$ and indicating that the cubic $\mathrm{ZrO}_{2}$ grains are surrounding the leftover tetragonal grains and protect them against hydrothermal degradation. When using these ceramics to fabricate monolithic dental restorations, the ageing resistance of such zirconia is important because of the possible risk of hydrothermal degradation. As mentioned in literature, glazing the monolithic restorations could not protect the zirconia framework from hydrothermal degradation like porcelain veneering does. The glazing can make the ageing problem 
even more critical because of a pit area [57]. The use of a pre-shaded zirconia block with better ageing stability can help avoiding any potential issue. The use of $\mathrm{Fe}_{2} \mathrm{O}_{3}$ as a dopant decreases hydrothermal ageing degradation and effectively colours the zirconia ceramic without the risk of fading because the dopants are incorporated in the ceramic lattice.
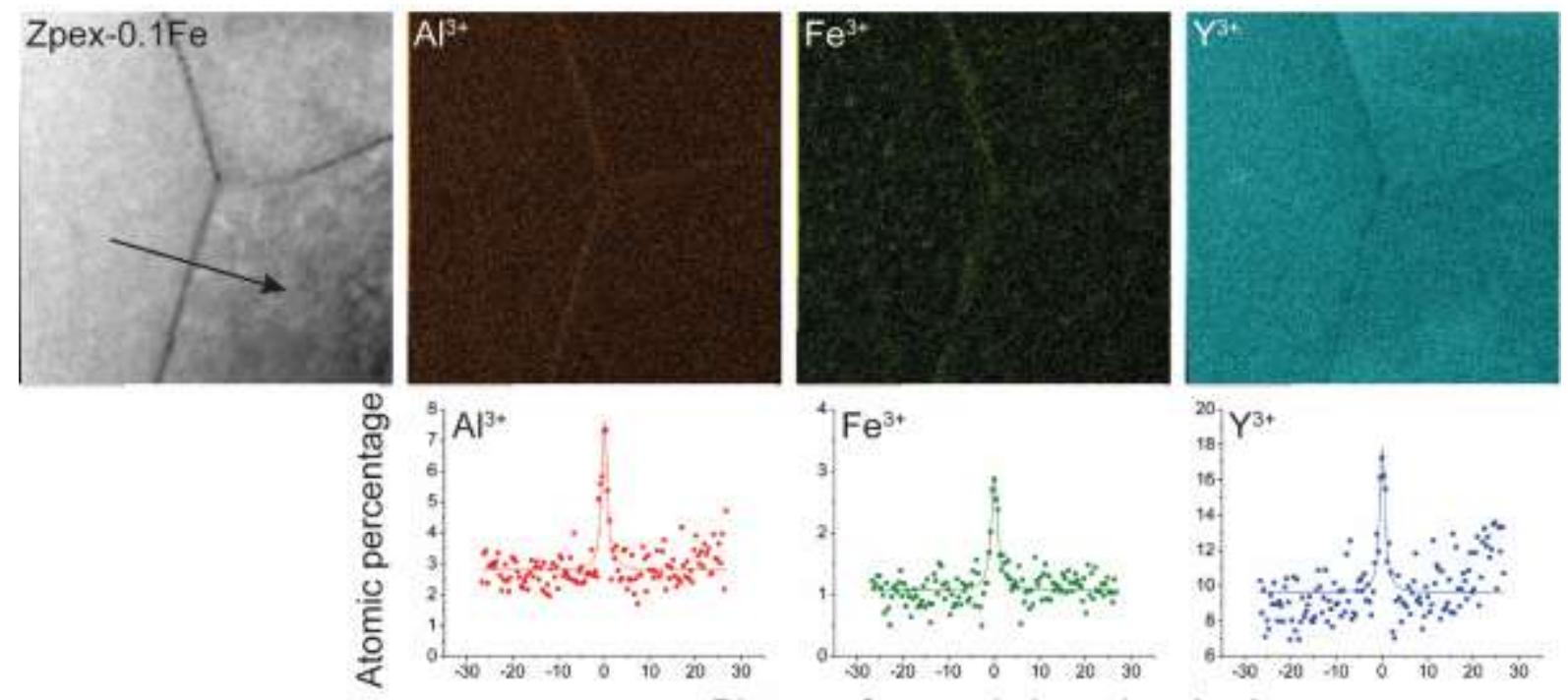

Distance from grain boundary $(\mathrm{nm})$

Figure 7: HAADF-STEM image of Zpex-0.1 Fe with corresponding STEM-EDS element maps and elemental distribution profiles over the grain boundary (the arrow shows the line scan location and direction)

\subsection{Translucency decreases with increasing $\mathrm{Fe}_{2} \mathrm{O}_{3}$ dopant}

The translucency data are summarised in Table 2 and presented in Fig. 8. Pure $\mathrm{Fe}_{2} \mathrm{O}_{3}$ free Zpex zirconia ceramics have the lowest contrast ratio (CR). This CR of $0.44 \pm$ 0.01 is even more translucent than reported for $\mathrm{Al}_{2} \mathrm{O}_{3}-$ and $\mathrm{La}_{2} \mathrm{O}_{3}-\mathrm{Co}$-doped 3Y-TZP ceramics [59], and zirconia ceramics of other brands [13]. The good translucency of Zpex zirconia ceramics results from the lower $\mathrm{Al}_{2} \mathrm{O}_{3}\left(0.05\right.$ wt\%) content [9]. The $\mathrm{Al}_{2} \mathrm{O}_{3}$ particles act as a light-scattering source, decreasing the translucency of zirconia $[50,59]$. No secondary $\mathrm{Al}_{2} \mathrm{O}_{3}$ particles were observed in any of the ceramics (Fig. 4).

Pure Zpex, Zpex Yellow and $0.01-0.1 \mathrm{Fe}_{2} \mathrm{O}_{3}$ doped Zpex had a similar grain size around $430 \mathrm{~nm}$ and an equal amount of cubic phase fraction of $13-14 \mathrm{vol} \%$ (Table 2). A smaller grain size improves the translucency of the zirconia ceramic $[9,60]$. To obtain a translucency that is comparable to that of teeth, the grain size of 3Y-TZP should be below $100 \mathrm{~nm}$ [9]. Since Zpex zirconia ceramics contain less $\mathrm{Al}_{2} \mathrm{O}_{3}$, the grains could be larger for pure $\mathrm{Fe}_{2} \mathrm{O}_{3}$-free Zpex zirconia ceramics, while still having a suitable translucency. Cubic phase zirconia shows a higher translucency than tetragonal phase zirconia, due to a lower birefringence. Increasing the yttria content to obtain this cubic phase is therefore a possibility to increase translucency [61], but would strongly 
decrease the fracture toughness of the zirconia ceramics [62]. Secondary phase iron oxide particles that could scatter the incoming light were not observed in the ceramics.

With the introduction of the $\mathrm{Fe}_{2} \mathrm{O}_{3}$ dopant, there was a small increase in porosity for the admixed ceramics (Table 1). Even a small amount of porosity considerably decreases translucency [63]. Zpex Yellow is the least translucent of all tested ceramics and showed no increase in porosity. Literature reported that the decreasing translucency of $\mathrm{Fe}_{2} \mathrm{O}_{3}$-doped Zpex is caused by the darker colour of $\mathrm{Fe}_{2} \mathrm{O}_{3}$ [64].

The $\mathrm{Fe}^{3+}$ cations that substitute $\mathrm{Zr}^{4+}$ create extra oxygen vacancies in the ceramics [31]. These colour centres will absorb light, decreasing the translucency of the material [65]. With increasing $\mathrm{Fe}_{2} \mathrm{O}_{3}$ doping, there will be more oxygen vacancies produced, decreasing the translucency, as observed by the increasing CR value in Table 2.

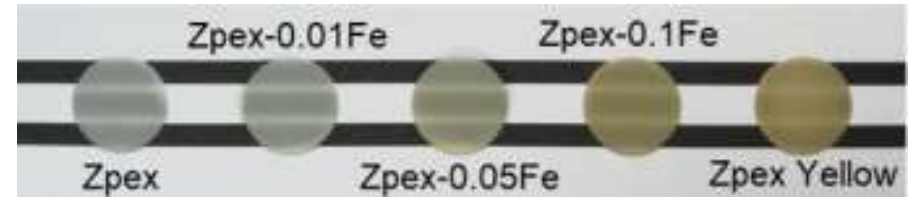

Figure 8: Translucency of the coloured zirconia ceramics

\section{Conclusions}

The present study shows that doping small amounts (0.01-0.1 mol\%) of $\mathrm{Fe}_{2} \mathrm{O}_{3}$ is a promising strategy to create tooth-coloured zirconia ceramics for dental restorations: (1) homogeneous colouring can be obtained; (2) colouration was obtained by incorporating $\mathrm{Fe}^{3+}$ in the zirconia lattice, which gives a stable colouring effect and indicates that dis-colouration will not occur within a reasonable life span; (3) $\mathrm{Fe}_{2} \mathrm{O}_{3}$ doping improves the hydrothermal aging stability. Although the ageing problem was not critical for conventional porcelain-fused-zirconia systems, it might be problematic for monolithic restorations, since there is no covering layer. Moreover, monolithic restorations need pre-shaded zirconia blocks to provide a naturally aesthetic outlook.

The $\mathrm{Fe}_{2} \mathrm{O}_{3}$-doped ceramics had a similar density $\left(6.07 \mathrm{~g} / \mathrm{cm}^{3}\right)$, composition (86 vol\% $\left.t-\mathrm{ZrO}_{2}, 14 \mathrm{vol} \% \quad c-\mathrm{ZrO}_{2}\right)$, grain size $(430 \mathrm{~nm})$, hardness $(13.1 \mathrm{GPa})$ and fracture toughness (4.8 $\mathrm{MPa} \mathrm{m}{ }^{1 / 2}$ ) as conventional 3Y-TZPs. Due to grain boundary segregation of $\mathrm{Fe}^{3+}$ in the ceramics, the oxygen vacancies are strongly bound in the space charge layer and hydrothermal ageing is slowed down with increasing amount of $\mathrm{Fe}_{2} \mathrm{O}_{3}$ dopant. These $\mathrm{Fe}_{2} \mathrm{O}_{3}$-doped ceramics were compared to Zpex Yellow, a $\mathrm{Fe}_{2} \mathrm{O}_{3}$-containing coprecipitated zirconia powder from Tosoh. The improved hydrothermal ageing resistance of co-precipitated powder (Zpex Yellow) based ceramics was less pronounced than for the $\mathrm{Fe}_{2} \mathrm{O}_{3}$-admixed powder-based ceramics due to the lower extent of $\mathrm{Fe}^{3+}$ grain-boundary segregation. The binder containing Zpex and Zpex Yellow powder-based ceramics showed a substantially higher strength after sintering, showing the importance of proper binder addition during processing of larger sized ceramics. 
Higher amounts of $\mathrm{Fe}_{2} \mathrm{O}_{3}$ doping (0.5-2 mol\%) not only revealed a colour that cannot be applied for dental restorations, but also resulted in a strong increase in larger grained cubic phase formation and residual porosity, and a subsequent decrease in density and mechanical properties.

\section{Acknowledgements}

This research was supported by the Research Fund of KU Leuven under project C217-00402 and the Fund for Scientific Research Flanders (FWO-Vlaanderen) under grant G.0431.10N. F. Zhang thanks the Fund for Scientific Research Flanders (FWOVlaanderen) for her post-doctoral fellowship (12S8418N). The authors acknowledge the Flemish Hercules Foundation under Project AKUL/1319 CombiS(T)EM). The authors thank Bensu Tunca Altintas for the TEM sample analysis, Wout Veulemans for the help with sample preparations and Ruben Büch for his contribution to the research. 


\section{References}

[1] F. Zarone, S. Russo, R. Sorrentino, From porcelain-fused-to-metal to zirconia: Clinical and experimental considerations, Dent. Mater. 27 (2011) 83-96.

[2] I. Sailer, N.A. Makarov, D.S. Thoma, M. Zwahlen, B.E. Pjetursson, All-ceramic or metal-ceramic tooth-supported fixed dental prostheses (FDPs)? A systematic review of the survival and complication rates. Part I: Single crowns (SCs), Dent. Mater. 31 (2015) 603-623.

[3] I. Sailer, B.E. Pjetursson, M. Zwahlen, C.H.F. Hämmerle, A systematic review of the survival and complication rates of all-ceramic and metal-ceramic reconstructions after an observation period of at least 3 years. Part II: Fixed dental prostheses, Clin. Oral Implants Res. 18 (2007) 86-96.

[4] P.C. Guess, S. Schultheis, E.A. Bonfante, P.G. Coelho, J.L. Ferencz, N.R.F.A. Silva, All-ceramic systems: Laboratory and clinical performance, Dent. Clin. North Am. 55 (2011) 333-352.

[5] T. Miyazaki, T. Nakamura, H. Matsumura, S. Ban, T. Kobayashi, Current status of zirconia restoration, J. Prosthodont. Res. 57 (2013) 236-261.

[6] C. Piconi, G. Maccauro, Zirconia as a ceramic biomaterial, Biomaterials. 20 (1999) 1-25.

[7] R.H.J. Hannink, P.M. Kelly, B.C. Muddle, Transformation Toughening in Zirconia-Containing Ceramics, J. Am. Ceram. Soc. 83 (2004) 461-487.

[8] P. Baldissara, A. Llukacej, L. Ciocca, F.L. Valandro, R. Scotti, Translucency of zirconia copings made with different CAD/CAM systems, J. Prosthet. Dent. 104 (2010) 6-12.

[9] Y. Zhang, Making Yttria-Stabilized Tetragonal Zirconia Translucent, Dent. Mater. 30 (2014) 1195-1203.

[10] L.H. da Silva, E. de Lima, R. Miranda, S. Favero, P. Cesar, Dental ceramics: a review of new materials and processing methods, Braz. Oral Res. 31 (2017) 133-146.

[11] Tosoh, Advanced Ceramics | Zirconia Powders - High Translucent Grades., https://www.tosoh.com/our-products/advanced-materials/zirconia-powders , 2017 (accessed 15 May 2018).

[12] M. Kern, V.P. Thompson, F. Beuer, R. Frankenberger, R.J. Kohal, K.H. Kunzelmann, P. Pospiech, B. Reis, All-Ceramics at a Glance, 3th Englis, Society for Dental Ceramics, Ettlingen, 2016.

[13] F. Tabatabaian, Color in Zirconia-Based Restorations and Related Factors: A Literature Review, J. Prosthodont. 27 (2018) 201-211.

[14] A. Hassan Ahangari, K. Torabi Ardakani, F. Mahdavi, M. Torabi Ardakani, The Effect of two Shading Techniques on Value of Zirconia-Based Crowns., J. Dent. (Shiraz, Iran). 16 (2015) 129-133.

[15] G. Kaya, Production and characterization of self-colored dental zirconia blocks, Ceram. Int. 39 (2013) 511-517. 
[16] J. Hjerppe, T. Närhi, K. Fröberg, P.K. Vallittu, L.V.J. Lassila, Effect of shading the zirconia framework on biaxial strength and surface microhardness, Acta Odontol. Scand. 66 (2008) 262-267.

[17] T.A. Sulaiman, A.A. Abdulmajeed, T.E. Donovan, P.K. Vallittu, T.O. Närhi, L. $V$. Lassila, The effect of staining and vacuum sintering on optical and mechanical properties of partially and fully stabilized monolithic zirconia, Dent. Mater. J. 34 (2015) 605-610.

[18] J. Chevalier, L. Germillard, Zirconia as a Ceramic Biomaterial, in: P. Ducheyne, K.E. Healy, D.W. Grainger, D.W. Hutmacher, J.C. Kirkpatrick (Eds.), Compr. Biomater., Volume 1:, Elsevier, 2011: pp. 95-108.

[19] ISO standard 13356: Implants for surgery -- Ceramic materials based on yttriastabilized tetragonal zirconia (Y-TZP), (2015).

[20] ISO standard 6872: Dentistry -- Ceramic materials, (2015).

[21] M.I. MENDELSON, Average Grain Size in Polycrystalline Ceramics, J. Am. Ceram. Soc. 52 (1969) 443-446.

[22] D.J. Chevalier J, Cales B, Low-temperature aging of Y-TZP ceramics, J Am Ceram Soc. 82 (1999) 2150-4.

[23] H. Toraya, M. Yoshimura, S. Somiya, Calibration Curve for Quantitative Analysis of the Monoclinic-Tetragonal ZrO 2 System by X-Ray Diffraction, J. Am. Ceram. Soc. 67 (1984) C-119-C-121.

[24] R.F. Johnson, W. A.; Mehl, Reaction Kinetics in Processes of Nucleation and Growth, Trans. Am. Inst. Min. Metall. Eng. 135 (1939) 416-441.

[25] H. Tsubakino, M. Hamamoto, R. Nozato, Tetragonal-to-monoclinic phase transformation during thermal cycling and isothermal ageing in yttria-partially stabilized zirconia, J. Mater. Sci. 26 (1991) 5521-5526.

[26] W.S. Wyszecki, Günter \& Stiles, Color Science: Concepts and Methods, Quantitative Data and Formulae, John Wiley \& Sons, New York, 2000.

[27] J. Schanda, CIE Colorimetry, in: Color. Underst. CIE Syst., John Wiley \& Sons, Inc., Hoboken, NJ, USA, 2007: pp. 25-78.

[28] H.G. Scott, Phase relationships in the zirconia-yttria system, J. Mater. Sci. 10 (1975) 1527-1535.

[29] K. Matsui, N. Ohmichi, M. Ohgai, H. Yoshida, Y. Ikuhara, Grain boundary segregation-induced phase transformation in yttria-stabilized tetragonal zirconia polycrystal, J. Ceram. Soc. Japan. 114 (2006) 230-237.

[30] F. Guo, P. Xiao, Effect of Fe2O3 doping on sintering of yttria-stabilized zirconia, J. Eur. Ceram. Soc. 32 (2012) 4157-4164.

[31] M.J. Verkerk, A.J.A. Winnubst, A.J. Burggraaf, Effect of impurities on sintering and conductivity of yttria-stabilized zirconia, J. Mater. Sci. 17 (1982) 31133122.

[32] V. Pouchly, K. Maca, Sintering kinetic window for yttria-stabilized cubic zirconia, J. Eur. Ceram. Soc. 36 (2015) 2931-2936. 
[33] K. Matsui, H. Horikoshi, N. Ohmichi, M. Ohgai, H. Yoshida, Y. Ikuhara, Cubicformation and grain-growth mechanisms in tetragonal zirconia polycrystal, J. Am. Ceram. Soc. 86 (2003) 1401-1408.

[34] J. Chevalier, S. Deville, E. Münch, R. Jullian, F. Lair, Critical effect of cubic phase on aging in 3 mol\% yttria-stabilized zirconia ceramics for hip replacement prosthesis, Biomaterials. 25 (2004) 5539-5545.

[35] D. Kim, T.-Y. Tien, Phase Stability and Physical Properties of Cubic and Tetragonal ZrO2 in the System ZrO2-Y2O3-Ta2O5, J. Am. Ceram. Soc. 74 (1991) 3061-3065.

[36] F. Zhang, M. Batuk, J. Hadermann, G. Manfredi, A. Mariën, K. Vanmeensel, M. Inokoshi, B. Van Meerbeek, I. Naert, J. Vleugels, Effect of cation dopant radius on the hydrothermal stability of tetragonal zirconia: Grain boundary segregation and oxygen vacancy annihilation, Acta Mater. 106 (2016) 48-58.

[37] Q. Dong, Z.H. Du, T.S. Zhang, J. Lu, X.C. Song, J. Ma, Sintering and ionic conductivity of 8YSZ and CGO10 electrolytes with small addition of Fe2O3: A comparative study, Int. J. Hydrogen Energy. 34 (2009) 7903-7909.

[38] G. Stefanic, B. Grzeta, K. Nomura, R. Trojko, S. Music, The influence of thermal treatment on phase development in $\mathrm{ZrO} 2-\mathrm{Fe} 2 \mathrm{O} 3$ and $\mathrm{HfO} 2-\mathrm{Fe} 2 \mathrm{O} 3$ systems., 327 (2001) 151-160.

[39] M.T. Groza, J.R. ; Shackelford, J.F. ; Laverania, E.J. ; Powers, Materials Processing Handbook, CRC Press, Boca Raton, 2007.

[40] M. Trunec, Z. Chlup, Higher fracture toughness of tetragonal zirconia ceramics through nanocrystalline structure, Scr. Mater. 61 (2009) 56-59.

[41] H. Tong, C.B. Tanaka, M.R. Kaizer, Y. Zhang, Characterization of three commercial Y-TZP ceramics produced for their High-Translucency, HighStrength and High-Surface Area, Ceram. Int. 42 (2016) 1077-1085.

[42] K. Matsui, H. Yoshida, Y. Ikuhara, Grain-boundary structure and microstructure development mechanism in $2-8 \mathrm{~mol} \%$ yttria-stabilized zirconia polycrystals, 56 (2008) 1315-1325.

[43] J. Eichler, J. Rödel, U. Eisele, M. Hoffman, Effect of grain size on mechanical properties of submicrometer 3Y-TZP: Fracture strength and hydrothermal degradation, J. Am. Ceram. Soc. 90 (2007) 2830-2836.

[44] D.-J. Kim, H.-J. Jung, J.-W. Jang, H.-L. Lee, Fracture Toughness, lonic Conductivity, and Low-Temperature Phase Stability of Tetragonal Zirconia Codoped with Yttria and Niobium Oxide, J. Am. Ceram. Soc. 81 (2005) 2309_ 2314.

[45] F. Zhang, K. Vanmeensel, M. Inokoshi, M. Batuk, J. Hadermann, B. Van Meerbeek, I. Naert, J. Vleugels, 3Y-TZP ceramics with improved hydrothermal degradation resistance and fracture toughness, J. Eur. Ceram. Soc. 34 (2014) 2453-2463.

[46] L. Ruiz, M.J. Readey, Effect of Heat Treatment on Grain Size, Phase Assemblage, and Mechanical Properties of 3 mol\% Y-TZP, J. Am. Ceram. Soc. 79 (1996) 2331-2340. 
[47] A. Bravo-Leon, Y. Morikawa, M. Kawahara, M.J. Mayo, Fracture toughness of nanocrystalline tetragonal zirconia with low ytttia content, Acta Mater. 50 (2002) 4555-4562.

[48] M. Trunec, Effect of Grain Size on Mechanical Properties of 3Y-TZP Ceramics, Ceram. Silikaty. 52 (2008) 165-171.

[49] M. Turon-Vinas, M. Anglada, Strength and fracture toughness of zirconia dental ceramics, Dent. Mater. 34 (2018) 365-375.

[50] A. Samodurova, A. Kocjan, M. V. Swain, T. Kosmac, The combined effect of alumina and silica co-doping on the ageing resistance of 3Y-TZP bioceramics, Acta Biomater. 11 (2015) 477-487.

[51] S. Hwang, I. Chen, Grain Size Control of Tetragonal Zirconia Polycrystals Using the Space Charge Concept, J. Am. Ceram. Soc. 77 (1990) 3269-3277.

[52] R.D. Shannon, Revised effective ionic radii and systematic studies of interatomic distances in halides and chalcogenides, Acta Crystallogr. Sect. A. 32 (1976) 751-767.

[53] J. Frenkel, Kinetic Theory of Liquids, Oxford University Press, New York, 1946.

[54] J. Chevalier, L. Gremillard, A. V. Virkar, D.R. Clarke, The tetragonalmonoclinic transformation in zirconia: Lessons learned and future trends, J. Am. Ceram. Soc. 92 (2009) 1901-1920.

[55] M.S. Khan, M.S. Islam, D.R. Bates, Cation doping and oxygen diffusion in zirconia: a combined atomistic simulation and molecular dynamics study, J. Mater. Chem. 8 (1998) 2299-2307.

[56] M.O. Zacate, L. Minervini, D.J. Bradfield, R.W. Grimes, K.E. Sickafus, Defect cluster formation in M2O3-doped cubic ZrO2, Solid State lonics. 128 (2000) 243-254.

[57] J.W. Kim, N.S. Covel, P.C. Guess, E.D. Rekow, Y. Zhang, Concerns of hydrothermal degradation in CAD/CAM Zirconia, J. Dent. Res. 89 (2010) 9195.

[58] E. Camposilvan, R. Leone, L. Gremillard, R. Sorrentino, F. Zarone, M. Ferrari, J. Chevalier, Aging resistance, mechanical properties and translucency of different yttria-stabilized zirconia ceramics for monolithic dental crown applications, Dent. Mater. 34 (2018) 879-890.

[59] F. Zhang, K. Vanmeensel, M. Batuk, J. Hadermann, M. Inokoshi, B. Van Meerbeek, I. Naert, J. Vleugels, Highly-translucent, strong and aging-resistant 3Y-TZP ceramics for dental restoration by grain boundary segregation, Acta Biomater. 16 (2015) 215-222.

[60] M. Stuer, Z. Zhao, U. Aschauer, P. Bowen, Transparent polycrystalline alumina using spark plasma sintering: Effect of Mg, Y and La doping, J. Eur. Ceram. Soc. 30 (2010) 1335-1343.

[61] F.F. Lange, Transformation toughening: Part 3, Experimental Observations in the ZrO2-Y2O3 System, J. Mater. Sci. 17 (1982) 240-246. 
[62] J. Klimke, M. Trunec, A. Krell, Transparent Tetragonal Yttria-Stabilized Zirconia Ceramics: Influence of Scattering Caused by Birefringence, J. Am. Ceram. Soc. 94 (2011) 1850-1858.

[63] L. Jiang, Y. Liao, Q. Wan, W. Li, Effects of sintering temperature and particle size on the translucency of zirconium dioxide dental ceramic, J. Mater. Sci. Mater. Med. 22 (2011) 2429-2435.

[64] F. Matsuzaki, H. Sekine, S. Honma, T. Takanashi, K. Furuya, Y. Yajima, M. Yoshinari, Translucency and flexural strength of monolithic translucent zirconia and porcelain-layered zirconia, Dent. Mater. J. 34 (2015) 910-917.

[65] J.E. Alaniz, F.G. Perez-Gutierrez, G. Aguilar, J.E. Garay, Optical properties of transparent nanocrystalline yttria stabilized zirconia, Opt. Mater. (Amst). 32 (2009) 62-68. 